\title{
Comparative Adaptability Assessment of Two Mangroves from Indian Sundarbans: Some Biochemical Appearances
}

\author{
Nirjhar Dasgupta, Pallavi Chowdhury, Sauren Das* \\ Agricultural and Ecological Research Unit, Indian Statistical Institute, Kolkata, India \\ Email: *sauren@isical.ac.in
}

Received 11 September 2015; accepted 20 November 2015; published 23 November 2015

Copyright (C) 2015 by authors and Scientific Research Publishing Inc.

This work is licensed under the Creative Commons Attribution International License (CC BY). http://creativecommons.org/licenses/by/4.0/

\section{(c) (i) Open Access}

\section{Abstract}

Comparative adaptability against salinity was assessed between the two well-known mangroves (Avicennia marina and Heritiera fomes) from Indian Sundarbans in vitro. Occurrence of $\boldsymbol{H}$. fomes is intermittent in and around of this mangrove swamp. A harmony has to maintain between ROS production and efficient scavenging of ROS by the plant itself for sustainability. In the present work, extent of salt tolerance was evaluated by mainly two ways: i) accumulation of free amino acids in the cytoplasm for proficient osmotic adjustment and ii) promoting elevated amount of antioxidants (both enzymes and secondary metabolites) with respect to substrate salinity. Occurrence of free amino acids (Alanine, Leucine and Proline) in $A$. marinaare well correlated (p $\leq 0.01$ ) with the increasing salinity and $H$. fomes (Alanine and Phenyl Alanine) correlation value showed $p$ $\leq 0.05$. ROS scavenging reflected through ABTS, DPPH and $\mathrm{Fe}^{2+}$ chelating activity and results indicating that $A$. marina have some advantage over the other investigated taxa. Amount of phenols and flavonoids also designated the same. Additional number of isoforms of two antioxidant enzymes (peroxidase and super oxide dismutase) occurred in $A$. marina as the salinity enhanced, but in case of $H$. fomes, which was lacking. The experimental results might be designated towards the comfortable adaptability to $A$. marina, rather to $H$. fomes.

\section{Keywords}

ABTS, DPPH, Free Amino Acids, Mangroves, Phenols

\section{Introduction}

Mangroves, being a productive and protective halophilic group of plant community dwell in along the tropical

\footnotetext{
${ }^{*}$ Corresponding author.
}

How to cite this paper: Dasgupta, N., Chowdhury, P. and Das, S. (2015) Comparative Adaptability Assessment of Two Mangroves from Indian Sundarbans: Some Biochemical Appearances. Natural Science, 7, 519-534. 
and subtropical estuaries of the world. Being a protective buffer against the frequency and ferocity of episodic cyclones, hurricanes, Tsunami, storms and floods; the significance of mangrove restoration has claimed a priority research. According to FAO report [1], 198,000 $\mathrm{km}^{2}$ of mangroves in 1980, and 157,630 km² in 1990 presently represents only 146,530 $\mathrm{km}^{2}$ across the globe. Development and industrialization have triggered the existence crisis of this important habitat [2] [3]. Simultaneously, relative sea level rise due to global climatic changes also has great impact on mangrove vegetation [4]. Duke et al. [5] opined that the decline of the mangrove forest occur at a faster rate than inland tropical forest and coral reef and postulated that $30 \%-40 \%$ of coastal wet lands and $100 \%$ of the mangrove forest could be lost in the next 100 years. Hence, an attentive responsiveness demands towards the potentiality of mangrove restoration programme.

Sundarbans, the largest single block of mangrove delta, includes two countries, India (West Bengal) and Bangladesh. Due to geomorphic features, an upliftment in the north-western part (India) and subsidence in the east (Bangladesh) has conquer an elevated salinity in the western part (India) which imparts a major impact on mangrove species distribution [6]. A cumulative effects of damming in the lower Gangetic plane, industrial pollution, geotectonic characteristics and unplanned reformation of coastal area have pave the way of massive siltation on the river bed which in turn, caused reduction of fresh water influx through the river system and its tributaries to the sea leading to hike salinity in the Indian Sundarbans [7]. These instigate disastrous (sometimes complete elimination) for some important plant species (such as Aegialitisrotundifolia, Heritierafomes, Nypafruticans, Xylocarpusgranatum and X. mekongensis) from the swamps [8]-[10]. Heritiera fomes prefers less than 5ppt salinity [11]. In India, this species is rapidly deteriorating (only 6\% of 100 sampling sites) [12]. H. fomes is considered as red listed category taxa [13]. Although the species diversity is highest in this region, the conservation and sustainable management presently need serious attention. The most important criteria of mangroves, is their $\mathrm{NaCl}$ tolerance at least up to seawater level ( 500 mM NaCl) [14] [15]. Moreover, mangroves are considered as potential models for studying the salt tolerance mechanisms in plants [16]. Hence, investigations on adaptive potential in mangroves might be in formative towards salt management.

Different mangrove species displays change in osmoregulation, which can be validated with excess accumulation of compatible solutes, like sugar, free amino acids and low molecular weight proteins [17] [18]. Dual effects of osmotic adjustment for cellular homoeostasis involve: uptake of inorganic ions and synthesis of compatible organic solutes within the cell sap [19]-[22]. To avoid ionic toxicity, absorbed inorganic ions are sequestered into the vacuole (especially $\mathrm{Na}^{+}$and $\mathrm{Cl}^{-}$) [23]-[25]. Occurrence of excess inorganic ions in the vacuole, the cytoplasm has to confront bi-phasic stresses: internal stress caused by the accumulated ions and external stress [26]. To minimise this conflict, plants accumulate de novo some organic compatible solutes like amino acids (e.g. proline, alanine, tyrosine etc.), soluble sugars (e.g. sucrose), polyols (e.g. mannitol), and betaines (e.g. glycine betaine) to adjust the osmotic potential, and moreover these organic solutes do not interfere with normal metabolic processes [14] [27]-[29]. However, the degree of salt tolerance can be attributed to the accumulation of compatible solutes in the cell sap [30].

Considerable scientific evidences suggested that under oxidative stress, reactive oxygen species (ROS) such as peroxyl, superoxide and hydroxyl radicals are generated and the ratio between oxidation and anti-oxidation is supposed to be a critical concept for maintaining a biological homeostasis [31]. Consequently, research on antioxidant principles of plants has been fast-tracked and halophytes have been recognized for marked antioxidant potential activities [32]. Polyphenols are antioxidants, having redox properties, act as reducing agents, hydrogen donators and singlet oxygen quenchers. A number of secondary metabolites were traced from mangroves time to time and have been recognized as pivotal bioactivities towards efficient slat management [33]-[35]. Despite of innumerable bioactivities, polyphenols perhaps are mostly attributed to antioxidant property [36]-[38]. Some essential phenols and flavonoids were traced from several mangroves [39]-[41].

Polyphenols in plants are well established as a defensive force against detrimental impact of abiotic stress which leads to generate free radicals [42]-[44]. The commonly determination methods of antioxidant activity are ABTS [2, 2'-azino-bis (3-ethylbenzothiazoline-6-sulphonicacid)] and DPPH (1, 1-diphenyl-2-picrylhydrazyl) assay. Both of them have intense reproducible characteristics under certain assay conditions. ABTS ${ }^{+}$is dissolved in aqueous and organic media, where in the antioxidant activity can be measured [45]. In contrast, DPPH has been used extensively as a free radical evaluating reducing substances [46]. DPPH is only soluble in organic media, especially in ethanol, this have a limitation while deducing the role of hydrophilic antioxidants.

Removal of $\mathrm{H}_{2} \mathrm{O}_{2}$ is vital for cellular DNA homeostasis [47]. The antioxidant capacity of compounds has been 
attributed to various factors such as prevention of chain reaction, chelating metals, radical scavenging ability and reductive capacity [48] [49]. Chelation of pro-oxidant metals is one of the most important mechanisms of action of secondary antioxidants. Iron and other transition metals (cobalt, copper, chromium, vanadium, arsenic, cadmiumand nickel) act as catalysts of free radical reactions promote oxidation. The transition metal ion, $\mathrm{Fe}^{2+}$ hold the capacity to shift single electrons by virtue of which it can allow the formation and proliferation of many radical reactions [50]. The main strategy to avoid ROS generation involves chelating of the metal ions that is associated with redox active metal catalysis.

Salt tolerance of plant is mainly attained by four mechanisms: 1) osmotic adjustment of the cytoplasm as a result of accumulation of compatible solutes; 2 ) exclusion of salt from the cell across the plasma membrane using ion transporters [51]-[53]; 3) accumulation of salt in the vacuoles using tonoplast transporters [54]-[57]; and 4) triggering on the elevated production of antioxidants (both enzymes and secondary metabolites) for scavenging reactive oxygen species [58]-[62]. A compulsory consequence of aerobic metabolism is generation of reactive oxygen species (ROS) which embrace free radicals such as superoxide anion $\left(\mathrm{O}_{2}{ }^{\circ}\right)$, hydroxylradical $(\cdot \mathrm{OH})$, as well as non-radical molecules like hydrogen peroxide $\left(\mathrm{H}_{2} \mathrm{O}_{2}\right)$, singlet oxygen $\left({ }^{1} \mathrm{O}_{2}\right)$. Salt tolerance in plant primarily relies on minimizing the water loss through stomata and metabolic shifting through toxic ion homeostasis and osmotic adjustment. On the other hand, it has been established that salt tolerance can be correlated with enhanced ROS scavenging ability [63]-[65]. Enzymes like Superoxide dismutase (SOD), Peroxidase (PRX), Catalase (CAT) are potentially involved in $\mathrm{H}_{2} \mathrm{O}_{2}$ metabolism leading to photo protection. An increased accumulation of PRX and SOD were reported in water logging stress in Kandeliacandel and Bruguieragymnorrhiza [66]. Antioxidative enzymes in relation to salt tolerance in different plants have been assessed much, but remain focused because of enhance accumulation of these antioxidant enzymes not only concomitant with salt tolerance, but also with salt sensitivity too [67]. Experimental evidence revealed that, elevated synthesis of antioxidative enzymes and increased number of their isoforms can be attributed in selection of salt resistant [68]. In view of the above, this work aims to understand the extent of salt tolerance of two mangroves (one of which is presently in alarming existence in Indian Sundarbans and rest one shows predominant occurrence in the same regime) by assessing the leaf water potential, some major free amino acids accumulation and regulation of two antioxidant enzymes (peroxidase and superoxide dismutase) across in different salinity gradients (in vitro experiments). These findings might be enlightening towards the probable reasons of their extinction and priority areas of preservation strategy.

\section{Materials and Methods}

Healthy seeds/fruits of two true mangroves (Avicennia marina and Heritiera fomes) were collected (Figure 1) from Indian Sundarbans (of which, $\mathrm{H}$. fomes is now in stress condition and the other one, Avicennia marina grown luxuriantly in the same habitat and were considered as natural control) and allowed to germinate in polythene bag in mesophytic soil. All the seedlings were grown up to a certain maturity with fresh water treatment for 30 days and thus maintained equable soil environments and age of the plants. After 30 days, the seedlings were treated with different concentrations of saline water $(100,200,300$ and $400 \mathrm{mM}$ of $\mathrm{NaCl}$ ), leaving one set of experimental pot (to be used as control). These salinity treatments (watering in every alternate day) were continued for another 30 days. At 60 days of maturity, young leaves were collected from three sets of seedlings from each treatment for further experiments.

Free amino acids: Six free amino acids (viz. Aspartic acid, Alanine, Leucine, Phenyl-Alanine, Proline and Tryptophan) were assayed from three taxa grown in different salinity gradients. Two grams of freeze-dried leaves were homogenized in acetone and the extracts were centrifuged at $6000 \mathrm{rpm}$ for $10 \mathrm{~min}$. Supernatants were subjected to thin layer chromatography [69] and spots were allowed to run in running buffer (mixture of 4:1:1 n-butanol, acetic acid and distilled water, $v / v$ ) up to an equal distances. In the chromatogram, greyish purple, bluish purple and yellow spots appeared for different amino acids, which were identified from their respective standard $\mathrm{R}_{\mathrm{mf}}$ values [69]. These spots were eluted by $80 \%$ ethanol and optical densities were measured in specific wavelengths (550 $\mathrm{nm}$ for proline and $400 \mathrm{~nm}$ for the other amino acids). Estimations were done based on standard curves plotted for individual amino acid. In case of tryptophan and tyrosine, where the $\mathrm{R}_{\mathrm{mf}}$ values were very close, confirmatory tests (Hopkins-Cole test for tryptophan and Millon's reaction for tyrosine) were performed following [69]. The value for each amino acid is the average of nine observations, i.e. three replica from each plant and three plants of each species. 


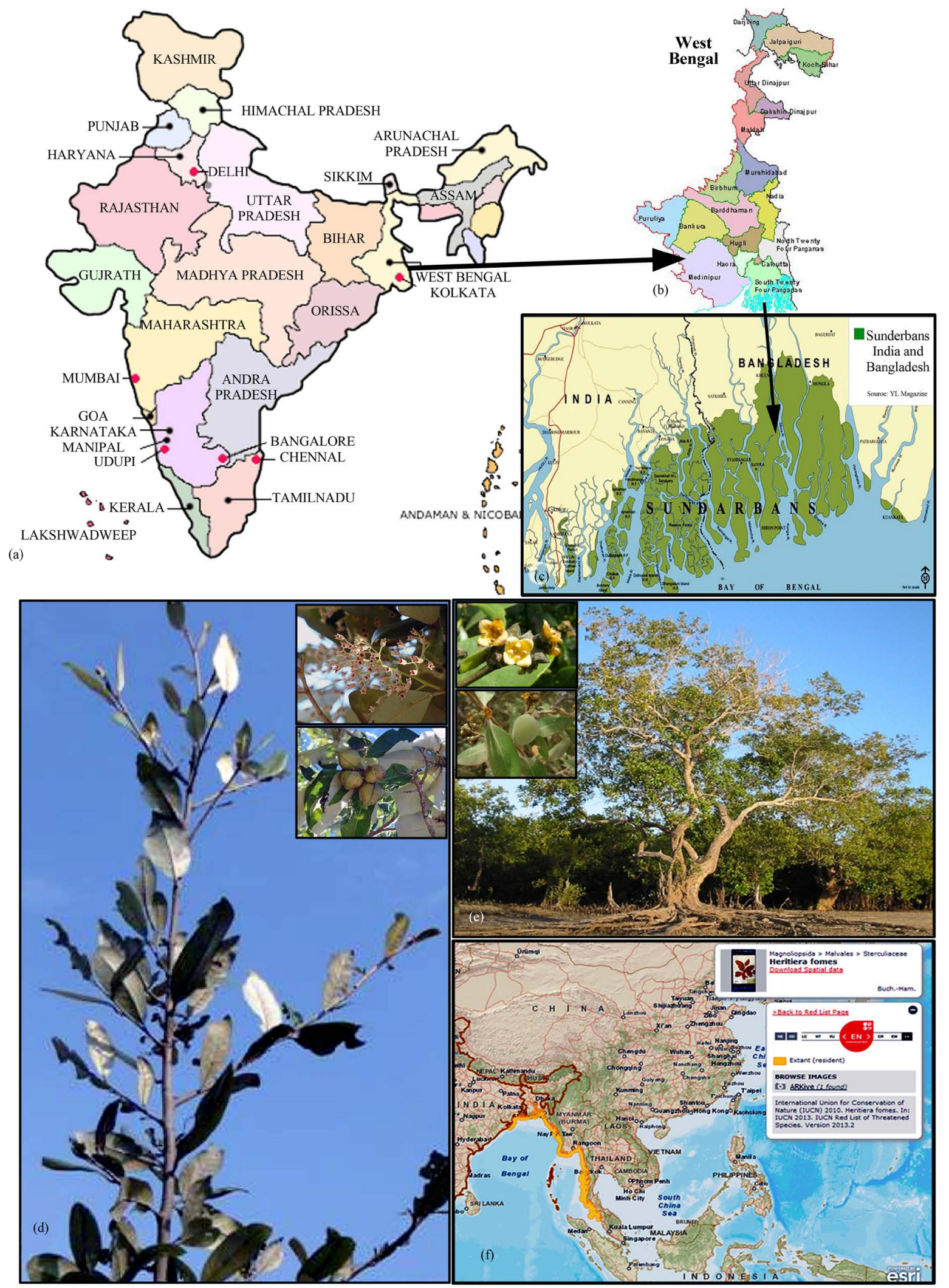

Figure 1. (a)-(c) Geographical Location of the study area; (d)-(e) Mature plants with flowering and fruiting twigs; (d) Heritierafomes; (e) Avicennia marina; (f) World distribution map of $H$. fomes according to ICUN. 


\subsection{Antioxidant Secondary Metabolites}

\section{Preparation of Extraction}

Methanolic extracts were prepared by maceration of $10 \mathrm{gm}$ of mature leaves (from the two taxa, each treatment) with $250 \mathrm{ml}$ of $95 \%$ ethanol, at room temperature for 24 hours and then filtered. The procedure was repeated thrice. The extracts were filtered and centrifuged (4500 rpm, $15 \mathrm{~min}$ ). The solvent was evaporated on rotary evaporator (Neocool Circulator, CF 300, Yamato). The concentrated methanolic leaf extracts were kept frozen $\left(-20^{\circ} \mathrm{C}\right)$ until further use [70].

Total Phenols: Folin-Ciocalteu method [71] was followed to determine the total phenol contents in the extracts. $0.1 \mathrm{ml}$ of extractant in methanol containing $0.05-0.3 \mathrm{mg} / \mathrm{ml}$ conc. of the leaf extract was mixed with 2 $\mathrm{ml}$ Folin-Ciocalteu reagent (previously diluted with water at 1:10 v/v) and $1.6 \mathrm{ml}(7.5 \%)$ of Sodium carbonate $\left(\mathrm{Na}_{2} \mathrm{CO}_{3}\right)$. The tubes were mixed and allowed to stand at room temperature for 30 min for color development. Spectrophotometer readings of absorbance were taken at $765 \mathrm{~nm}$ using. Gallic acid in the same concentration as the sample was used as positive control. The total phenolic content was expressed as Gallic acid equivalents (GAE) in milligram per gram of dry material using the calibration curve, where $\mathrm{X}$ was the absorbance and $\mathrm{Y}$ was the Gallic acid equivalent ( $\left.\mathrm{mg} \cdot \mathrm{g}^{-1}\right)$.

Total Flavonoids: Estimation of total flavonoids in the plant extracts were carried out following the method of Jia et al. [72]. In $0.1 \mathrm{ml}$ of extractant in methanol containing $0.2-1.2 \mathrm{mg} / \mathrm{ml}$ conc. of the leaf extract, $1.2 \mathrm{ml}$ distilled water, $0.120 \mathrm{ml}$ of $5 \%$ Sodium nitrite $\left(\mathrm{NaNO}_{2}\right)$ were added and mixed vigorously. Keep the mixture at $25^{\circ} \mathrm{C}$ temperature for 5 mins. After that $0.120 \mathrm{ml}$ of $10 \% \mathrm{AlCl}_{3}$ solution was added and mixed thoroughly. Then the tubes are allowed to stand at room temperature for 5 minutes. Then $0.8 \mathrm{ml}$ of $1 \mathrm{mM}$ Sodium hydroxide $(\mathrm{NaOH})$ solution and $1.16 \mathrm{ml}$ distilled water were added. The absorbances were measured at $510 \mathrm{~nm}$. Quercetin in the same concentration as the sample was used as positive control. Total flavonoids content was calculated as Quercetin (mg $\cdot \mathrm{g}^{-1}$ ) using the calibration curve, where X was the absorbance and Y was the Quercetin equivalent $\left(\mathrm{mg} \cdot \mathrm{g}^{-1}\right)$.

\subsection{ROS Scavenging Ability Assay}

DPPH• quenching assay: The free radical scavenging activity of different plant extracts were determined using the stable radical DPPH (1,1-diphenyl-2-picrylhydrazyl) following Blois [73]. A freshly prepared DPPH solution $\left(25 \mathrm{mg} \cdot \mathrm{L}^{-1}\right)$ in methanol was prepared and $3.9 \mathrm{ml}$ of this solution was mixed with $0.1 \mathrm{ml}$ of extract in methanol containing $0.05-0.3 \mathrm{mg} / \mathrm{ml}$ conc. of the extract. $30 \mathrm{~min}$ later, the absorbances were measured at 517 nm using Spectrophotometer (Helios $\gamma$, Thermo Electron Corporation). Butylated Hydroxy Toluene (BHT) in the same concentration as the sample was used as positive control. The capability to scavenge the DPPH radical was calculated using the following equation:

$$
\text { DPPH radical scavenging activity }(\%)=\left\{\frac{A c-A t}{A c}\right\} \times 100
$$

where $A c$ is the absorbance of the blank reaction and At is the absorbance in presence of the sample of the extracts.

ABTS $^{+}$scavenging assay: The method of Re et al. [74] was adopted to determine ABTS [2, 2'-azino-bis (3-ethylbenzothiazoline-6-sulphonic acid)] radical scavenging assay. The stock solutions included 7 mM ABTS solution and $2.4 \mathrm{mM}$ Potassium Per sulfate solution. The working solution was then prepared by mixing the two stock solutions in equal quantities and allowing them to react for 12 hour at room temperature in the dark. The solution was then diluted by mixing $1 \mathrm{ml}$ ABTS solution with $60 \mathrm{ml}$ methanol. Fresh ABTS solution was prepared for each assay. Plant extracts $(0.1 \mathrm{ml})$ in methanol containing $0.005-0.03 \mathrm{mg} / \mathrm{ml}$ conc. of the extract were allowed to react with $3 \mathrm{ml}$ of the ABTS solution and the absorbances were taken at $734 \mathrm{~nm}$ after $7 \mathrm{~min}$ using Spectrophotometer. Butylated Hydroxy Toluene (BHT) in the same concentration as the sample was used as positive control. The ABTS scavenging capacity of the extract was calculated as:

$$
\text { ABTS radical scavenging activity }(\%)=\left\{\frac{A c-A t}{A c}\right\} \times 100
$$

where $A c$ is the absorbance of the blank reaction and At is the absorbance in presence of the sample of the 
extracts.

$\mathbf{F e}^{2+}$ chelation activity: The method described by Haro-Vicente et al. [75] was followed for assessing the chelating capacity of the plant extracts for ferrous ion. The reaction was carried out in 20 mM HEPES buffer, pH 7.2. Different aliquots of the plant extract, ranging from $0.05-0.3 \mathrm{mg} / \mathrm{ml}$ were added to $12.5 \mathrm{mM}$ ferrous sulfate solution and the reaction was initiated by the addition of ferrozine $(75 \mathrm{mM})$. The reaction mixture was shaken vigorously which followed incubation for $20 \mathrm{~min}$ at room temperature. The absorbances were measured at $562 \mathrm{~nm}$. EDTA in the same concentration as the sample was used as positive control. The Fe ${ }^{2+} \mathrm{Chelation} \mathrm{ca-}^{2}$ pacity of the extract was calculated as:

$$
\mathrm{Fe}^{2+} \text { Chelationability }(\%)=\left\{\frac{A c-A t}{A c}\right\} \times 100
$$

where Ac is the absorbance of the blank reaction and At is the absorbance in presence of the sample of the extracts.

In all scavenging/chelating ability are expressed in terms of $\mathrm{IC}_{50}$. It is defined as the concentration of the plant extract that's needed to scavenge/chelate $50 \%$ of the scavengers/chelating ions present were calculated by the following equation:

$$
\mathrm{IC}_{50}=\left\{\frac{\text { Perccent inhibition }}{\text { Concentration of the Sample }}\right\} \times 50
$$

\subsection{Estimation of Enzymes: Gel Electrophoresis}

Extraction of enzymes: Two grams of young leaf buds were macerated to powder with liquid Nitrogen in a mortar-pestle and then added with $0.1 \mathrm{gm}$ PVP and $5 \mathrm{ml}$ of extraction buffer ( $1 \mathrm{M}$ Sucrose, $0.2 \mathrm{M}$ Tris- $\mathrm{HCl}$ and $0.056 \mathrm{M} \beta$-Marcaptoethanol; pH was adjusted at 8.5 after volume make up by double distilled water). The homogenates were centrifuged at $1500 \mathrm{rpm}$ for $20 \mathrm{~min}$ at $4^{\circ} \mathrm{C}$ and use the supernatants in PAGE analysis.

PAGE analysis: Equimolar amounts of proteins (leaf extracts) were loaded in each well. Different isoforms of enzymes were separated by native gel electrophoresis. Gels were stained for definite enzyme following Das and Mukherjee [76]. Gels were documented with a Gel-Doc System (Biostep GmbH - Germany) and analysis for band intensity and Relative Mobility Factor $\left(\mathrm{R}_{\mathrm{mf}}\right)$ were performed with Kodak-MI software. This experiment was repeated five times with the same molecular weight markers. In each case, the number of isoforms and respective OD values were obtained at more or less same $R_{m f}$.

\subsection{Enzyme Assay}

Peroxidase (PRX, E.C.1.11.1.7): From $200 \mathrm{mg}$ fresh leaf, extraction was prepared in $1-1.5 \mathrm{ml}$ of $0.9 \% \mathrm{KCl}$ and centrifuged at $12,000 \mathrm{rpm}$ for $15 \mathrm{~min}$ at $4^{\circ} \mathrm{C}$; the supernatants used as enzyme sample. Absorbance's were taken spectrophotometrically (Helios $\gamma$, Thermo electron Corporation, USA) at $460 \mathrm{~nm}$ with respect to the standard curve prepared following Shannon et al. [77] with minute modification.

Superoxide dismutase (SOD, E.C.1.15.1.1): Cell sap extracted by macerating $200 \mathrm{mg}$ of leaf in 1 - $1.5 \mathrm{ml}$ of $50 \mathrm{mM}$ Phosphate buffer, $\mathrm{pH}$ adjusted to 7.0 and centrifuged at $12,000 \mathrm{rpm}$ for $15 \mathrm{~min}$ at $4^{\circ} \mathrm{C}$. The supernatants used as enzyme samples. Standard curves were prepared with pure enzyme samples at different aliquots (50, 100, 150, 200, $250 \mu \mathrm{g} \cdot \mathrm{ml}^{-1}$ ). Absorbances were measured at $550 \mathrm{~nm}$ following the protocol described by Keith et al. [78] with slight modification.

The value for each species is the average of nine observations, i.e. three replica from each plant and three plants of each species. SPSS 12.0 version was employed for all the statistical calculations.

\section{Results}

Estimation of free amino acids: Among the six amino acids investigated in leaves of the two species (A. marina and $H$. fomes) grown at different $\mathrm{NaCl}$ treatment (control, 100, 200, 300 and $400 \mathrm{mM}$ ) resulted that not all six amino acids occur in both the species except Aspartic acid (Asp) and Alanine (Ala). Apart from these two, A. marina possesses Leucine (Leu) and Proline (Pro) and instead of Leucine and Proline, $H$. fomes have PhenylAlanine (Phe) and Tryptophan (Trp). In Avicennia, Asp, Ala, Leu and Pro were recorded as 11.37, 3.48, 3.74 
and $9.73 \mu \mathrm{g} \cdot \mathrm{g}^{-1}$ leaf weight respectively in control plants; sharp increment up to $400 \mathrm{mM}$ substratum observed in all the amino acids were detected $\left(19.15,29.95,26.36\right.$ and $47.39 \mu \mathrm{g} \cdot \mathrm{g}^{-1}$ respectively) except Asp, where amount increased was less than the other three. In Avicennia, the trend line of proline increment according to salinity rise was most prominent (9.73 in control to 47.39 , in $400 \mathrm{mM}$ saline treatment). In Heritiera, Asp increment occurred over control up to $200 \mathrm{mM}$ salinity $\left(12.54\right.$ to $\left.22.21 \mu \mathrm{g} \cdot \mathrm{g}^{-1}\right)$; beyond this, it was decreased. Similarly, Ala, Phe and Trp were observed in the approach of augmentation up to $300 \mathrm{mM} \mathrm{NaCl}$ concentration (23.03, 11.96 and $11.93 \mu \mathrm{g} \cdot \mathrm{g}^{-1}$ respectively) and drop down at $400 \mathrm{mM}\left(20.63\right.$, 9.51 and $7.44 \mu \mathrm{g} \cdot \mathrm{g}^{-1}$ respectively) (Figure 2(a)).

Incidence of total phenols: Estimated total phenol (TP) in different salinity level of the two studied mangroves is much higher over the control one. It is expressed as Gallic acid equivalent (GAE) in all cases. In Avicennia, TP is observed as gradual increment according to the gradual increment of substrate salinity $\left(19.28 \mathrm{mg} \cdot \mathrm{g}^{-1}\right.$ in control and $39.41 \mathrm{mg} \cdot \mathrm{g}^{-1}$ in $400 \mathrm{mM}$ saline concentration). But this trend did not occur in Heritiera, where the augmentation of TP over control treatment is recorded up to $200 \mathrm{mM}$ of $\mathrm{NaCl}$ treatment $\left(12.65 \mathrm{mg} \cdot \mathrm{g}^{-1}\right.$ and $31.54 \mathrm{mg} \cdot \mathrm{g}^{-1}$

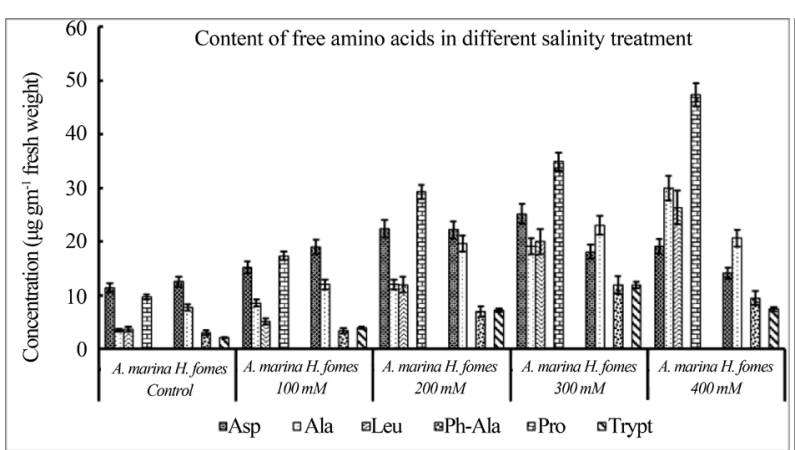

(a)

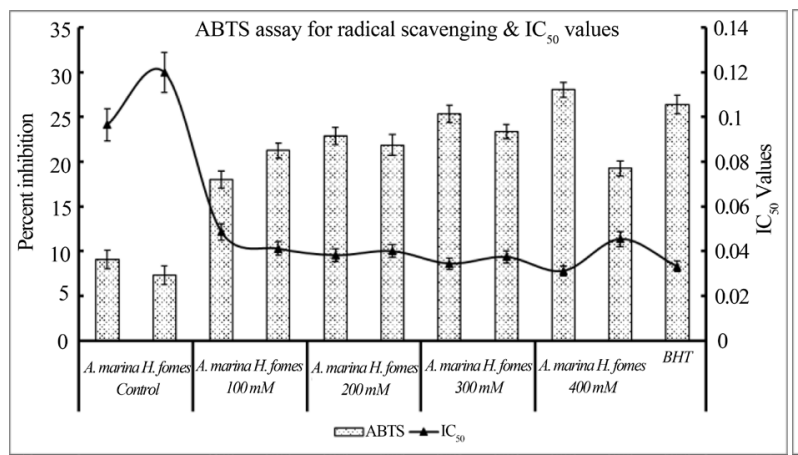

(c)

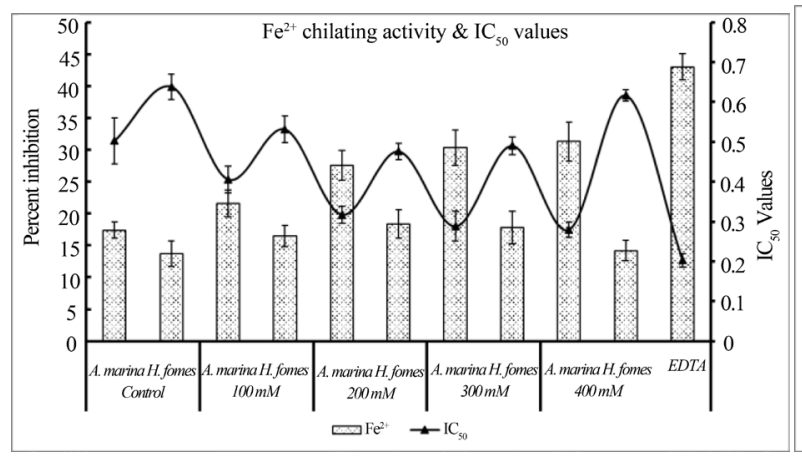

(e)

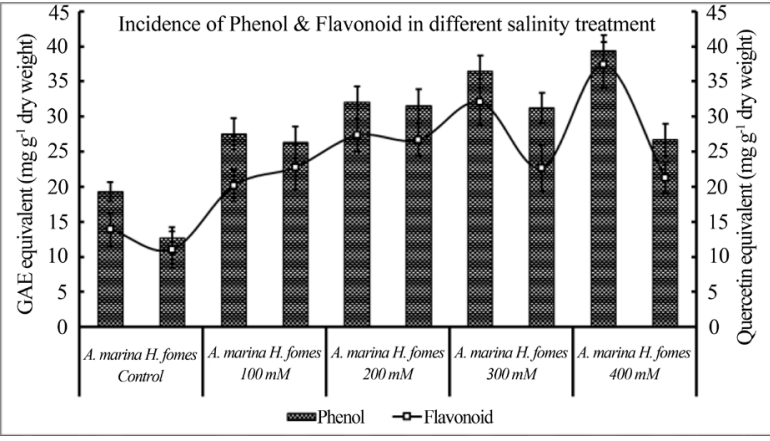

(b)

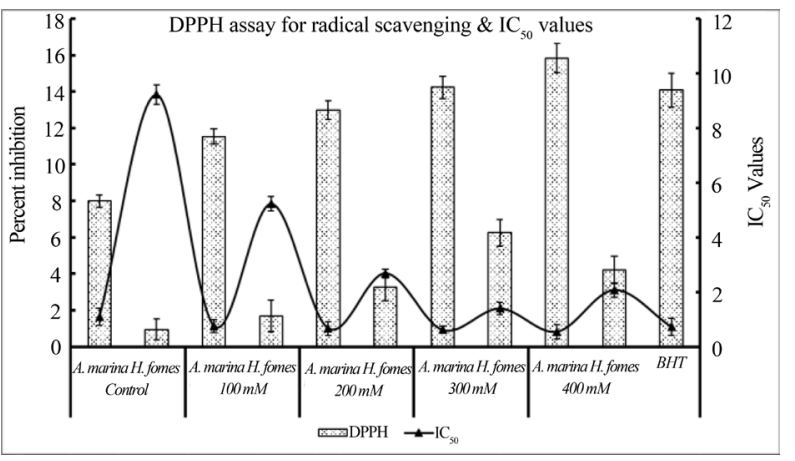

(d)

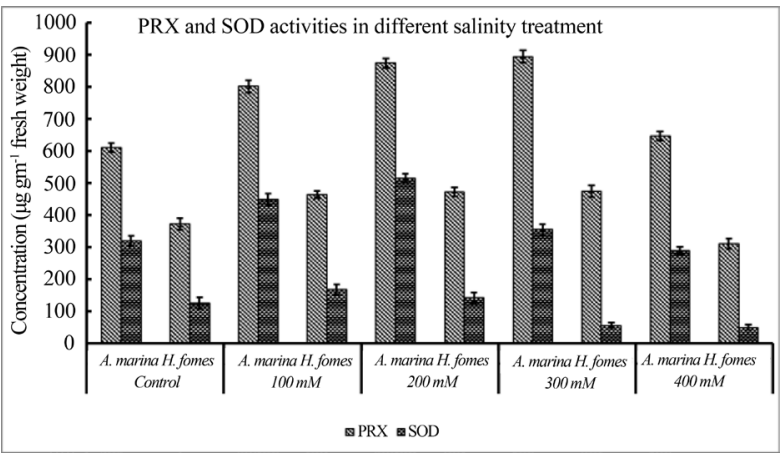

(f)

Figure 2. Graphical representation of different assay results. (a) Phenol and Flavonoid contains in different salinity treatment; (b) Amino acids contains in different salinity treatments; (c) ABTS assay and IC $_{50}$ values; (d) DPPH assay and IC $_{50}$ values; (e) $\mathrm{Fe}^{2+}$ chelating activity and $\mathrm{IC}_{50}$ values; (f) PRX and SOD activities in different salinity treatment. 
respectively); the amount was more or less unchanged in $300 \mathrm{mM}\left(31.2 \mathrm{mg} \cdot \mathrm{g}^{-1}\right)$ and instead of increment in 400 $\mathrm{mM}$, it was depleted $\left(26.7 \mathrm{mg} \cdot \mathrm{g}^{-1}\right.$ ) (Figure 2(b)).

Incidence of total flavonoids: The incidence of total flavonoids (TF) was expressed in Quercetin equivalent in the present work. Like TP, total flavonoid was assessed as a considerable increment as salinity increased from 0 to $400 \mathrm{mM}$ of $\mathrm{NaCl}$ treatment in Avicennia (13.96 mg. $\mathrm{g}^{-1}$ and $37.4 \mathrm{mg} \cdot \mathrm{g}^{-1}$ ), but the trend is quite dissimilar in case of Heritiera, where the escalation recorded up to $200 \mathrm{mM}$ of $\mathrm{NaCl}$ treatment over the control one (11.06 and $26.71 \mathrm{mg} \cdot \mathrm{g}^{-1}$ respectively) and it considerably dropped down in 300 and $400 \mathrm{mM}$ of $\mathrm{NaCl}$ treatment (22.68 and $21.28 \mathrm{mg} \cdot \mathrm{g}^{-1}$ respectively) (Figure 2(b)).

ABTS $^{+}$scavenging assay: The trend observed in this assay is quite similar to DPPH scavenging assay. The magnitude of percent reduction of ROS increase in case of A. marina is tremendous from Control to $100 \mathrm{mM}$ treatment $(9.06 \%$ - $18.01 \%)$ following which the increment is gradual with maximum at $400 \mathrm{mM}$ of $\mathrm{NaCl}$ treatment (28.02\%). Similarly in case of $H$. fomes, relative increase in value of ABTS activity is evident from Control to $300 \mathrm{mM}(7.29 \%-23.35 \%)$, while a decrease is apparent with $400 \mathrm{mM}$ treatment (19.24\%). Also a trace amount of increment is observed from $100 \mathrm{mM}$ to $200 \mathrm{mM}$ (21.25\% - 21.85\%). Reference BHT value was observed to be $26.36 \%$. Highest $\mathrm{IC}_{50}$ value for $H$. fomeswas found at control treatment $(0.11 \%)$ and the lowest at $300 \mathrm{mM}(0.037 \%)$ and in A. marina maximum at control $(0.096 \%)$ and lowest in $400 \mathrm{mM} \mathrm{NaCl}$ treatment (0.031\%) (Figure 2(c)).

DPPH assay for radical scavenging: The DPPH assay in different salinity level of the two studied taxaon an average showed a continuous increase in percent reduction of evolved ROS according to the gradual increment of substrate salinity. In A. marina the DPPH assay value is maximum in $400 \mathrm{mM} \mathrm{NaCl}$ treated plant (15.54\%) which is much higher than the control value (7.98\%). Whereas in case of $H$. fomes, the trend was dissimilar with an increment from control (0.94\%) to $300 \mathrm{mM} \mathrm{NaCl}$ treated plant $(6.24 \%)$ and a decrease at $400 \mathrm{mM} \mathrm{NaCl}$ (4.21\%) respectively. The value of DPPH activity in case of the positive control (BHT) was found to be $14.08 \%$. $\mathrm{IC}_{50}$ values were calculated in all the cases which reflected the usual reverse diagrams. $\mathrm{IC}_{50}$ is inversely proportional to percent inhibition. Experimental results showed that the maximum $\mathrm{IC}_{50}$ value in $H$. fomes at control treatment (9.21\%) and minimum in A. marina at $400 \mathrm{mM}$ treatment (0.55\%) (Figure 2(d)).

$\mathbf{F e}^{+2}$ chelation activity: It is evident from the experiment that the $\mathrm{Fe}^{2+}$ chelation activity in case of $A$. marina is found to be constant hike from control (17.42\%) to $400 \mathrm{mM}$ of $\mathrm{NaCl}$ treatment (31.29\%) but the rate of change is not same in all treatments (e.g. increment from $300 \mathrm{mM}$ to $400 \mathrm{mM}$ is. $30.37 \%-31.29 \%$ ). $\mathrm{H}$. fomes showed a different form of chelation activity with an increment from Control to $200 \mathrm{mM}(13.71 \%-18.39 \%)$ and a gradual decrease in $300 \mathrm{mM}(17.86 \%)$ and $400 \mathrm{mM}(14.2 \%)$ with the lowest value at control (13.71\%). The positive control, EDTA showed a value of $43.02 \%$ which is higher as compared to A. marina and $H$. fomes. $\mathrm{IC}_{50}$ value showed similar trends as DPPH and ABTS with the maximum in $H$. fomes at control (0.63\%) and lowest for A. marina at $400 \mathrm{mM}$ treatment (0.27\%) (Figure 2(e)).

\subsection{Quantitative Assay of PRX and SOD}

Peroxidase: Experimental results showed increase in the amount of PRX enzyme in case of A. marina from control to $300 \mathrm{mM}\left(610.56-894.56 \mu \mathrm{g} \cdot \mathrm{g}^{-1}\right) \mathrm{NaCl}$ treatment while a depletion occurs at $400 \mathrm{mM}$ treatment $\left(647.08 \mu \mathrm{g} \mathrm{g}^{-1}\right)$. The results obtained from $\mathrm{H}$. fomes, where maximum value is observed at $300 \mathrm{mM}$ treatment $\left(474.78 \mu \mathrm{g} \cdot \mathrm{g}^{-1}\right.$ ) over the control following which the value decreased to $309.86 \mu \mathrm{g} \cdot \mathrm{g}^{-1}$ at $400 \mathrm{mM} \mathrm{NaCl}$ treatment, though the increment from $200 \mathrm{mM}$ to $300 \mathrm{mM}$ is nominal but in $400 \mathrm{mM}$ saline treated plants giving a value less than control plant (372.08\%) (Figure 2(f)).

Superoxide Dismutase: Increase in SOD level is evident in case of A. marina from control to $200 \mathrm{mM}$ treatment $\left(317.86 \mu \mathrm{g} \cdot \mathrm{g}^{-1}\right)$, where after it dropped down at $300 \mathrm{mM}\left(354.04 \mu \mathrm{g} \cdot \mathrm{g}^{-1}\right)$ and $400 \mathrm{mM}\left(289.06 \mu \mathrm{g} \cdot \mathrm{g}^{-1}\right)$ $\mathrm{NaCl}$ treatment. Unlikely $\mathrm{H}$. fomes showed increase till $100 \mathrm{mM}$ treatment $\left(167.07 \mu \mathrm{g} \cdot \mathrm{g}^{-1}\right)$ but when treated with $200 \mathrm{mM} \mathrm{NaCl}$ treatment the amount of enzyme depleted to $141.83 \mu \mathrm{g} \cdot \mathrm{g}^{-1}$ and lowest at $400 \mathrm{mM}(49.07$ $\mu \mathrm{g} \cdot \mathrm{g}^{-1}$ ) (Figure 2(f)).

\subsection{PAGE Analysis}

Peroxidase: Experimental data shows that A. marina expresses comparatively more bands than $H$. fomes, two bands appear in Control treatment with $(138.2,151.74)$ ODs at their respective $R_{m f}$ values are $(0.31,0.47)$; in $100 \mathrm{mM}$ treatment of $\mathrm{NaCl}$ number of bands increased to three (147.93, 153.00188 .97 ; $\mathrm{R}_{\mathrm{mf}}$ 's are $0.31,0.48$ and 
0.66 respectively), further an increment in band number is observed in $200 \mathrm{mM}$ and $300 \mathrm{mM} \mathrm{NaCl}$ treatment where four (OD 127.0, 131.0, 122.44, 138.6; $\mathrm{R}_{\mathrm{mf}} \mathrm{S}$ are 0.31, 0.42, 0.66, 0.73 respectively) and five (OD 18.4, 26.02, 16.76, 18.96, 53.34; $\mathrm{R}_{\mathrm{mf}} \mathrm{s}$ are $0.09,0.18,0.47,0.59,0.68$ respectively) bands are expressed respectively, where after the count decreased to three at $400 \mathrm{mM} \mathrm{NaCl}$ treatment. In $H$. fomes, unlike A. marina three bands occur under Control treatment (O.D. 28.53, 2.49, 1.99; $\mathrm{R}_{\mathrm{mf}}$ values are 0.25, 0.4, 0.57 respectively), which remained same at $100 \mathrm{mM}$ (O.D. 158.45, 128.77, 90.09; $\mathrm{R}_{\mathrm{mf}}$ 's values are 0.24, 0.44, 0.58 respectively), further at $200 \mathrm{mM}$ treatment of $\mathrm{NaCl}$, bands increased to four (O.D. 72.64, 39.3, 74.1, 82.65; $\mathrm{R}_{\mathrm{mf}} \mathrm{S}$ are $0.24,0.34,0.42,0.6$ respectively). A considerable decrease in the band number is noticed at 300 (OD 160,131; $R_{m f}$ 's are 0.06 and 0.31 ) and $400 \mathrm{mM}$ with two bands per concentration of $\mathrm{NaCl}$ treatment (Figure 3(a), Figure 3(b)).

Superoxide Dismutase: In case of A. marina, plants showed similar band expressions as peroxidase. Plants under control treatment showed two bands at OD 189.0 and 245.0 with respective $\mathrm{R}_{\mathrm{mf}}$ values are 0.19 and 0.37 . An increase in band number is seen when plant is treated with $100 \mathrm{mM} \mathrm{NaCl}$ (OD 127.4, 146.6, 168.4; $\mathrm{R}_{\mathrm{mf}} \mathrm{s}$ are 0.17, 0.36 and 0.49 respectively) which continued to increase till $200 \mathrm{mM} \mathrm{NaCl}$ (OD 178.0, 186.0, 222.0, and 26.1, $\mathrm{R}_{\mathrm{mf}} \mathrm{S}$ are $0.1,0.37,0.48$ and 0.53 respectively) and then the band number dropped at $300 \mathrm{mM} \mathrm{NaCl}$ (OD 63.0, 126.5, 103.45, 65.31; $\mathrm{R}_{\mathrm{mf}} \mathrm{S}$ are 0.06, 0.2, 0.31 and 0.42) and more at $400 \mathrm{mM} \mathrm{NaCl}$ treatment, the number of band depleted (OD 44, 104; $\mathrm{R}_{\mathrm{mf}} \mathrm{s}$ are $\left.0.14,0.42\right)$. SOD graph for $H$. fomes showed three bands under control, $100 \mathrm{mM}$ and $200 \mathrm{mM} \mathrm{NaCl}$ treatment (OD 5.43, 6.48, 5.42; $\mathrm{R}_{\mathrm{mf}} \mathrm{s}$ are 0.33, 0.63, 0.75 and 110.51, 53.32, 67.72; $\mathrm{R}_{\mathrm{mf}} \mathrm{S}$ are $0.04,0.26,0.54$ and 42.98, 162.2, 70.59; $\mathrm{R}_{\mathrm{mf}} \mathrm{S}$ are 0.08, 0.21, 0.34). Bands number dropped down to two at $300 \mathrm{mM}$ and $400 \mathrm{mM} \mathrm{NaCl}$ (OD 48.59, 29.58 at 0.54, 0.1 and 48.06, 67.4 at 0.34, 0.58 $\mathrm{R}_{\mathrm{mf}}$ ) (Figure 3(c), Figure 3(d)).

A two tailed bivariate correlation results shows that in A. marina, the available free amino acids, studied polyphenols, two antioxidant enzymes and ROS scavenging activity are positively correlated with the salinity imposed during experiments (either $\mathrm{P} \leq 0.01$ or $\mathrm{P} \leq 0.05$ level). To the contrary, in $H$. fomes, except leucine and phenyl alanine, all parameters are not correlated with the increment of salinity level (Table 1).

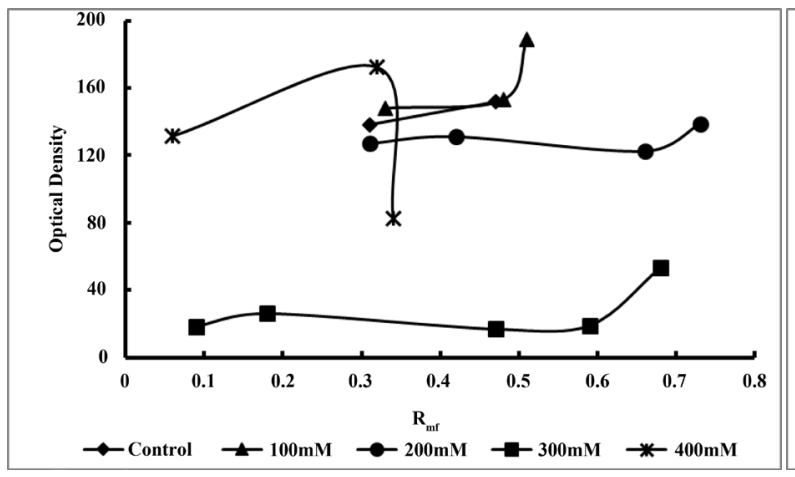

(a)

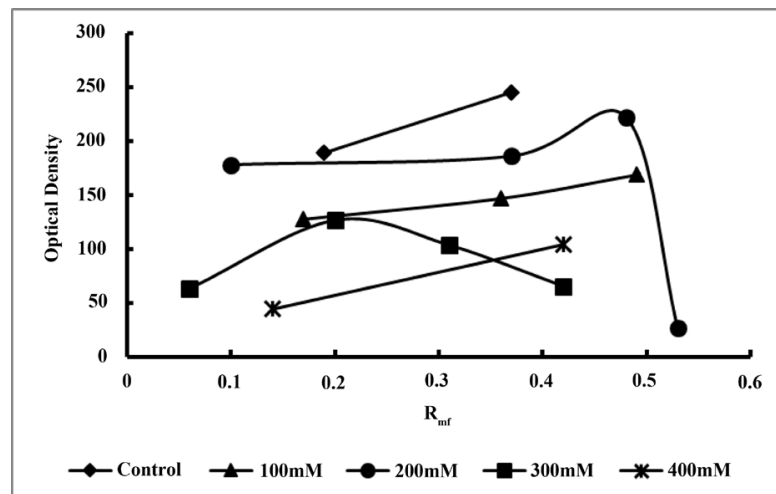

(c)

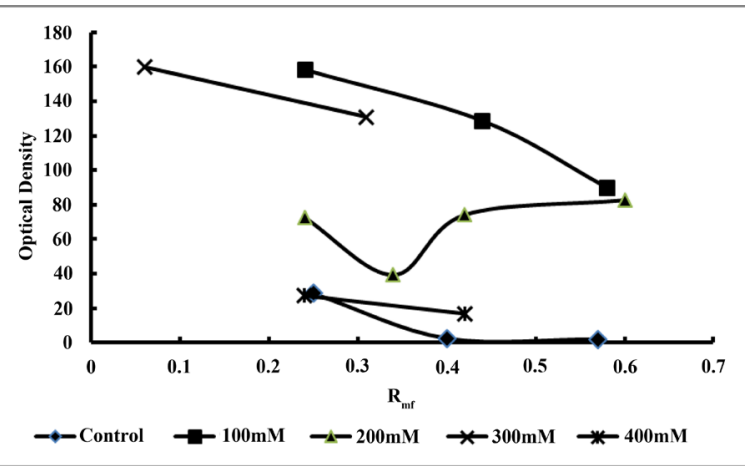

(b)

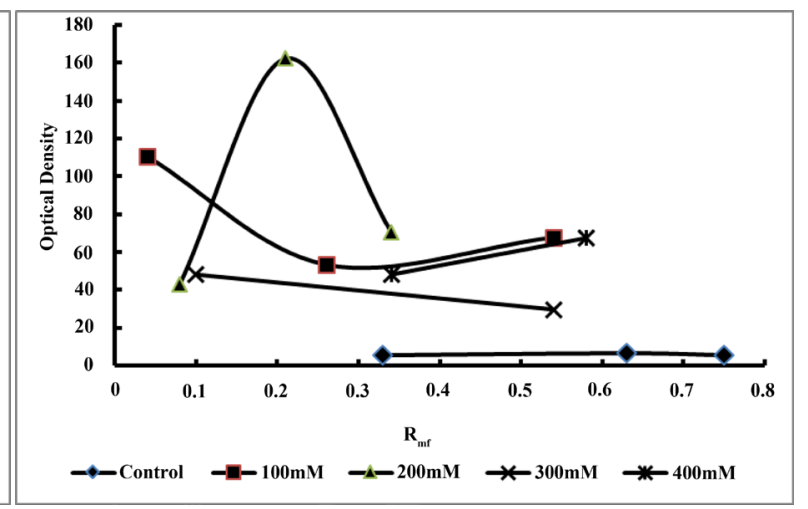

(d)

Figure 3. Graphical expression of the results obtained from Gel electrophoresis showing Optical Density and $\mathrm{R}_{\mathrm{mf}}$ values of two enzymes. (a) A. marina (PRX); (b) H. fomes (PRX); (c) A. marina (SOD); (d) H. fomes (SOD). 
Table 1. Correlation of different parameters with salinity.

\begin{tabular}{cccc}
\hline Parameter & Avicennia marina & Heritiera fomes & Parameter \\
PRX & 0.202 & 0.241 \\
SOD & 0.256 & 0.790 \\
Asp & 0.731 & 0.088 & $0.902^{*}$ \\
Ala & $0.976^{* *}$ & - \\
Leu & $0.981^{* *}$ & $0.880^{*}$ & Salinity \\
PhAla & - & - \\
Pro & $0.994^{* *}$ & 0.783 \\
Trypt & - & 0.678 \\
Phenol & $0.982^{* *}$ & 0.548 \\
Flavonoid & $0.997^{* *}$ & 0.633 \\
ABTS & $0.959^{*}$ & 0.835 \\
DPPH & $0.974^{* *}$ & 0.178 \\
Fe & $0.969^{*+}$ & $0.01\left(2\right.$-tailed). ${ }^{*}$ Correlation is significant at the $\mathrm{P} \leq 0.05$ (2-tailed).
\end{tabular}

\section{Discussion}

Reactive oxygen species (ROS) are shaped from usual bi-product of plant metabolic activity. Any environmental disaster leads to enhanced fabrication of ROS which instigate progressive oxidative damage and ultimately triggering apoptosis. Even their destructive activity, they are considered as additional messengers towards conferment of tolerance to ecological hassles. A harmony between ROS assembly and their scavenging is maintained for proper signal transduction and defense against premature oxidative destruction to the plant cells [34] [35]. Competent scavenging of unwanted ROS created during any environmental stresses involves several non-enzymatic as well as enzymatic antioxidants activities in the tissues. In this work, we describe a comparative analysis of incidence of ROS scavenging enzymes and secondary metabolites in two true mangroves from Sundarbans mangrove forest in different salinity treatment (in vitro) in relation to their sustainability. The fact that the occurrence non-enzymatic factors and enzymatic disparities play an important role towards their sustainability has been discussed in detail.

The magnitude of salt adaptation is determined by a number of biochemical pathways that include retention and/or acquisition of water (water potential of cells), protecting chloroplast functions and conserving ion homeostasis. The synthesis and accumulation of low molecular weight metabolites, known (compatible solutes), is an omnipresent device for osmotic adjustment in plants. Their main role is to increase water potential $(\psi)$ without hindering the normal metabolism [79]. In the present study, in A. marina, Aspartic acid, Alanine, Leucine and Proline play an essential role towards higher water potential and offer a better adaptability in high substrate salinity. Whereas, in $H$. fomes, among the studied free amino acid only Alanine and Phenyl alanine sowing correlation (at $\mathrm{P} \leq 0.05$ level) with salinity, but the other two (Aspertic acid and Tryptophan) are not significantly correlated and complete absent of Proline. These indicate relatively less adaptive ability in higher salt concentration. Munns [80] opined that high salinity hinder important physiological processes, such as photosynthesis and nutrient uptake, which are due to the reduction of leaf water potential. The increase of alanine in stressed leaves leading to excess glycolysis for enhanced respiration for the requirement of higher energy for salt sequestration in the vacuoles and endow with carbon skeletons for the photorespiration [81]. Enhanced production of Leucine and tryptophan signify the change occurs in protein synthesis in excess salt substratum [82]. Increment of Proline was also reported in salt stressed plants, as it helps to maintain required $\Psi$ during stress [83]. Increments of Asp, Ala, Leu and Pro with enhanced salinity indicate the better adaptability of A. marina over $H$. fomes. Synthesis and accumulation of free amino acids in plant cells are considered as adaptive stress response of the plant [84] and regarded as compatible solute that adjust osmotic potential in cytoplasm [85] [86]. Parida et al. [18] 
experimentally showed that in the cell sap of Bruguiera parviflora, the increment of osmotic solutes, like total sugar and total free amino acids occurred in various degrees under $\mathrm{NaCl}$ treatment and those osmoregulatory solutes help to restore the water potential more negative and might be consider as marker of extent of salt tolerance.

Oxidative damage of the plant cell relies broadly on the delicate equipoise between ROS production, and their efficient scavenging. Competent scavenging of ROS produced during various abiotic stresses involves the exploit of several non-enzymatic as well as enzymatic antioxidants present in the cells. In the present work, among the two taxa, A. marina shows a steady state increment of phenol and flavonoid along the salinity gradient but this trend do not occur in $H$. fomes, phenol and flavonoid both show an increment up to $200 \mathrm{mM}$ of salinity and drop down beyond this. Radical scavenge (per cent inhibition) estimation with ABTS, DPPH and $\mathrm{Fe}^{2+}$ chelating assays experiments reveal a considerable augmentation along salinity ascent in case of $A$. marine which are not found in the other taxa. Ebrahimzadeh et al. [87] experimentally proved that the highest chelating activity and the largest amount of phenolic compounds were found in Mellilotus arvensis. Mishra and Das [88] indicated that the non-secretor mangrove Bruguiera parviflora grows as alt tolerance appliance through elevated level of antioxidative enzymes and escalation in osmolytes like proline to acclimatize under salt stress condition.

Antioxidative enzymes mediated toxic ion homeostasis is an essential progression of a plant in abiotic stress. The present work reveals that both antioxidative enzymes PRX and SOD produced either added number of isoforms or enhanced activity (qualitative and quantitative estimation) along the increased salinity treatment in case of A. marina over the control treatment than that of $H$. fomes, in which, the increment in both estimations hiked up to certain level, beyond which it dropped down. Jetesh et al. [89] concluded that the antioxidant enzymes protect halophytes from deleterious ROS production and accumulation in cytoplasm during salt stress. Hence, extent of salt tolerant differ in the investigated taxa and salt tolerant can be attributed to the enhance accumulation of compatible osmolytes in the cell sap (free amino acids) as well as increased production of non-enzymatic ROS foragers like phenols and flavonoids and antioxidant enzymes (PRX and SOD).

Abogadallah [67] commented that elevated antioxidant activity could be inferred as better tolerance to oxidative stress; the plant suffers less oxidative stress due to higher antioxidant activity. Mallik et al. [90] experimentally proved the activity of both CAT and SOD increased significantly and also resulted in the synthesis of new isoforms of both CAT and SOD in response to the $\mathrm{NaCl}$ treatment among a group of plants. Turkan et al. [91] worked on antioxidant activity on two strains of Plantago (P. maritima, salt-tolerant and P. media, salt-sensitive) in water logging and salinity stressed condition and opined that a salt-tolerant species showed an amplified antioxidant activity against lipid peroxidation towards salt-tolerance than a salt-sensitive one. In plants, ROS are being generated through lickage during electron transport systems of chloroplasts, mitochondria, and plasma membranes [92]-[94]. Abiotic stresses such as drought, salinity, chilling, metal toxicity, and UV-B radiation disrupt the cellular homeostasis and lead to boosted generation of ROS [95] [96]. The present observation in respect of well correlated with the incidence of free amino acids and antioxidants (both enzymatic and non-enzymatic components) with salinity treatment might be specifying towards the advantage of A. marina than $\mathrm{H}$. fomes for sustainable existence in present days' elevated substrate salinity.

\section{References}

[1] Food and Agricultu. ral Organization, United Nations (FAO) (2007) The World's Mangroves 1980-2005. FAO Forestry Paper 153, FAO, Rome, 153 p.

[2] Alongi, D.M. (2009) The Energetics of Mangrove Forests. Springer, Dordrecht, 216 p.

[3] Giri, C., Ochieng, E., Tieszen, L.L., Zhu, Z., Singh, A., Loveland, T., Masek, J. and Duke. N.C. (2011) Status and Distribution of Mangrove Forests of the World Using Earth Observation Satellite Data. Global Ecology and Biogeography, 20, 154-159. http://dx.doi.org/10.1111/j.1466-8238.2010.00584.x

[4] Gilman, E., Ellison, J., Duke, N. and Field, C. (2008) Threats to Mangroves from Climate Change and Adaptation Options: A Review. Aquatic Botany, 89, 237-250. http://dx.doi.org/10.1016/j.aquabot.2007.12.009

[5] Duke, N.C., Meynecke, J.O., Dittmann, S., Ellison, A.M., Anger, K., Berger, U., Cannicci, S., Diele, K., Ewel, K.C., Field, C.D., Koedam, N., Lee, S.Y., Marchand, C., Nordhaus, I. and Dahdouh-Guebas, F. (2007) A World without Mangroves? Science, 317, 41-42. http://dx.doi.org/10.1126/science.317.5834.41b

[6] Chanda, S. and Datta, S.C. (1986) Prospects and Problems of a Mangrove Ecosystem in Western Sundarbans (India). Transactions of the Bose Research Institute, 49, 47-57.

[7] Nandy, P., Dasgupta, N. and Das, S. (2009) Differential Expression of Physiological and Biochemical Characters of Some Indian Mangroves towards Salt Tolerance. Physiology and Molecular Biology of Plants, 15, 151-160. 
http://dx.doi.org/10.1007/s12298-009-0017-7

[8] Banerjee, L.K. (1999) Mangroves of Orissa Coast and Their Ecology. Bishen Singh Mohendra Pal Singh, DehraDun, p 41.

[9] Parani, M., Lakshmi, M., Zeigenhagen, B., Fladung, M., Senthilkumar, P. and Parida, A. (2000) Molecular Phylogeny of Mangroves VII.PCR/RFLP of trnS-pbsC and rbcL Gene Regions in 24 Mangrove and Mangrove Associate Species. Theoretical and Applied Genetics, 100, 454-460. http://dx.doi.org/10.1007/s001220050059

[10] Upadhaya, V.P., Ranjan R. and Singh J.S. (2002) The Human Mangrove Conflicts-The Way Out. Current Science, 83, 1328-1336.

[11] Alim, A. (1979) Instruction Manual for Plantations in Coastal Areas. In: White, K.L., Ed., Research Considerations in Coastal Afforestation, Food and Agricultural Organization, UNDP/FAO Project BDG/72/005, Forest Research Institute, Chittgong, 65-75.

[12] Kathiresan, K. (2008) Threats to Mangroves. Degradation and Destruction of Mangroves. Centre of Advanced Study in Marine Biology, Annamalai University, Annamalai Nagar, 476-483.

[13] IUCN (2013) IUCN Red List of Threatened Species. Version 2013.2. www.iucnredlist.org

[14] Takemura, T., Hanagata, N., Sugihara, K., Baba, S., Karube, I. and Dubinsky, Z. (2000) Physiological and Biochemical Responses to Salt Stress in the Mangrove, Bruguiera gymnorrhiza. Aquatic Botany, 68, 15-28. http://dx.doi.org/10.1016/S0304-3770(00)00106-6

[15] Yan, L. and Guizhu, C. (2007) Physiological Adaptability of Three Mangrove Species to Salt Stress. Acta Ecologica Sinica, 27, 2208-2214. http://dx.doi.org/10.1016/S1872-2032(07)60052-3

[16] Hibino, T., Meng, Y.-L., Kawamitsu, Y., Uehara, N., Matsuda, N., Tanaka, Y., Ishikawa, H., Baba, S., Takabe, T., Wada, K., Ishii, T. and Takabe, T. (2001) Molecular Cloning and Functional Characterization of Two Kinds of Betaine-Aldehyde Dehydrogenase in Betaine-Accumulating Mangrove Avicennia marina (Forsk.) Vierh. Plant Molecular Biology, 45, 353-363.

[17] Popp, M., Polania, J. and Weiper, M. (1993) Physiological Adaptations to Different Salinity Levels in Mangrove. In: Lieth, H. and Al Masoom, A., Eds., Towards the Rational Use of High Salinity Tolerant Plants, Springer, Dordrecht, 217-224. http://dx.doi.org/10.1007/978-94-011-1858-3_22

[18] Parida, A., Das, A.B. and Das, P. (2002) NaCl Stress Causes Changes in Photosynthetic Pigments, Proteins and Other Metabolic Components in the Leaves of a True Mangrove, Bruguiera parviflora, in Hydroponic Cultures. Journal of Plant Biology, 45, 28-36. http://dx.doi.org/10.1007/BF03030429

[19] Morgan, J.M. (1984) Osmoregulation and Water Stress in Higher Plants. Annual Review of Plant Physiology, 35, 299348. http://dx.doi.org/10.1146/annurev.pp.35.060184.001503

[20] Kura-Hotta, M., Mimura, M., Tsujimura, T., Washitani-Nemoto, S. and Mimura, T. (2001) High Salt Treatment Induced $\mathrm{Na}^{+}$Extrusion and Low Salt Treatment Induced $\mathrm{Na}^{+}$Accumulation in Suspension Cultured Cells of the Mangrove Plant, Bruguiera sexangula. Plant, Cell and Environment, 24, 1105-1112. http://dx.doi.org/10.1046/j.0016-8025.2001.00761.x

[21] Mimura, T., Hura-Hotta, M., Tsujimura, T., Ohnishi, M., Miura, M., Okazaki, Y., Mimura, M., Maeshima, M. and Washitani-Nemoto, S. (2003) Rapid Increase of Vacuolar Volume in Response to Salt Stress. Planta, 216, 397-402.

[22] Joseph, B. and Jini, D. (2011) Development of Salt Stress-Tolerant Plants by Gene Manipulation of Antioxidant Enzymes. Asian Journal of Agricultural Research, 5, 17-27. http://dx.doi.org/10.3923/ajar.2011.17.27

[23] Flowers, T.J., Troke, P.F. and Yeo, A.R. (1977) The Mechanism of Salt Tolerance in Halophytes. Annual Review of Plant Physiology, 28, 89-121. http://dx.doi.org/10.1146/annurev.pp.28.060177.000513

[24] Greenway, H., Munns, R. and Wolfe, J. (1983) Interactions between Growth, $\mathrm{Cl}^{-}$and $\mathrm{Na}^{+}$Uptake, and Water Relations of Plants in Saline Environments. I. Slightly Vacuolated Cells. Plant, Cell and Environment, 6, 567-574. http://dx.doi.org/10.1111/j.1365-3040.1983.tb01170.x

[25] Muns, R. and Tester, M. (2008) Mechanisms of Salt Tolerance. Annual Review of Plant Physiology, 59, 651-681. http://dx.doi.org/10.1146/annurev.arplant.59.032607.092911

[26] Kamel, M. (2008) Osmotic Adjustment in Three Succulent Species of Zygophyllaceae. African Journal of Ecology, 46, 96-104. http://dx.doi.org/10.1111/j.1365-2028.2007.00823.x

[27] Aziz, I. and Khan, M.A. (2001) Experimental Assessment of Salinity Tolerance of Ceriops tagal Seedlings and Saplings from the Indus Delta, Pakistan. Aquatic Botany, 70, 259-268. http://dx.doi.org/10.1016/S0304-3770(01)00160-7

[28] Parida, A.K. and Das, A.B. (2005) Salt Tolerance and Salinity Effects on Plants: A Review. Ecotoxicology and Environmental Safety, 60, 324-349. http://dx.doi.org/10.1016/j.ecoenv.2004.06.010

[29] Flowers, T.J. and Colmer, T.D. (2008) Salinity Tolerance in Halophytes. New Phytologist, 179, 945-963. http://dx.doi.org/10.1111/j.1469-8137.2008.02531.x 
[30] Rabie, G.H. and Almadini, A.M. (2005) Role of Bio-Inoculants in Development of Salt Tolerance of Vicia faba Plants under Salinity Stress. African Journal of Biotechnology, 4, 210-222.

[31] Davies, K.J.A. (2000) Oxidative Stress, Antioxidant Defenses and Damage Removal, Repair and Replacement Systems. IUBMB Life, 50, 279-289. http://dx.doi.org/10.1080/15216540051081010

[32] Tiwari, A.K. (2001) Imbalance in Antioxidant Defense and Human Diseases: Multiple Approach of Natural Antioxidant Therapy. Current Science, 8, 1179-1187.

[33] Bandarnayake, W.M. (2002) Bioactivities, Bioactive Compounds and Chemical Constituents of Mangrove Plants. Wetlands Ecology and Management, 10, 421-452. http://dx.doi.org/10.1023/A:1021397624349

[34] Ravikumar, S., Gnanadesigan, M., Suganthi, P. and Ramalakshmi, A. (2010) Antibacterial Potential of Chosen Mangrove Plants against Isolated Urinary Tract Infectious Bacterial Pathogens. International Journal of Medicine and Medical Sciences, 2, 94-99.

[35] Ravikumar, S., Ramanathan, G., Inbaneson, S.J. and Ramu, A. (2011) Antiplasmodial Activity of Two Marine Polyherbal Preparations from Chaetomorpha antennina and Aegiceras corniculatum against Plasmodium falciparum. Parasitology Research, 108, 107-113. http://dx.doi.org/10.1007/s00436-010-2041-5

[36] Shahidi, F. (2000) Antioxidants in Food and Food Antioxidants. Food/Nahrung, 44, 158-163.

[37] Cushnie, T.P.T. and Lamb, A.J. (2005) Antimicrobial Activity of Flavonoids. International Journal of Antimicrobial Agents, 26, 343-356. http://dx.doi.org/10.1016/j.ijantimicag.2005.09.002

[38] Alam, N., Hossain, M., Khalil, M.I., Moniruzzaman, M., Sulaiman, S.A. and Gan, S.H. (2011) High Catechin Concentrations Detected in Withania somnifera (Ashwagandha) by High Performance Liquid Chromatography Analysis. BMC Complementary and Alternative Medicine, 11, 65. http://dx.doi.org/10.1186/1472-6882-11-65

[39] Vadlapudi, V. and Naidu, K.C. (2009) Evaluation of Antioxidant Potential of Selected Mangrove Plants. Journal of Pharmacy Research, 2, 1742-1745.

[40] Krishnamoorthy, M., Sasikumar, J.M., Shamna, R., Pandiarajan, C., Sofia, P. and Nagarajan, B. (2011) Antioxidant Activities of Bark Extract from Mangroves, Bruguiera cylindrica (L.) Blume and Ceriops decandra Perr. Indian Journal of Pharmacology, 43, 557-562. http://dx.doi.org/10.4103/0253-7613.84972

[41] Li, Y.X., Yu, S.J., Liu, D., Proksch, P. and Lin, W.H. (2012) Inhibitory Effects of Polyphenols toward HCV from the Mangrove Plant Excoecaria agallocha L. Bioorganic and Medicinal Chemistry Letter, 22, 1099-1102. http://dx.doi.org/10.1016/j.bmcl.2011.11.109

[42] Ostrowskaa, J., Łuczaja, W., Kasackab, I., Różańskic, A. and Elżbieta, S.E. (2004) Green Tea Protects against Ethanol-Induced Lipid Peroxidation in Rat Organs. Alcohol, 32, 25-32. http://dx.doi.org/10.1016/j.alcohol.2003.11.001

[43] Zurina, H., Yam, M.F., Mariam, A., Ahmad, P. and Pauzi, M.Y. (2010) Antidiabetic Properties and Mechanism of Action of Gynura procumbens Water Extract in Streptozotocin-Induced Diabetic Rats. Molecules, 15, 9008-9023. http://dx.doi.org/10.3390/molecules15129008

[44] Lee, H.-W., Hakim, P., Rabu, A.H. and Sani, A. (2012) Antidiabetic Effect of Gynura procumbens Leaves Extracts Involve Modulation of Hepatic Carbohydrate Metabolism in Streptozotocin-Induced Diabetic Rats. Journal of Medicinal Plants Research, 6, 796-812.

[45] Arnao, M.B. (2000) Some Methodological Problems in the Determination of Antioxidant Activity Using Chromogen Radicals: A Practical Case. Trends in Food Science \& Technology, 11, 419-421. http://dx.doi.org/10.1016/S0924-2244(01)00027-9

[46] Duan, X.J., Zhang, W.W., Li, X.M. and Wang, B.G. (2006) Evaluation of Antioxidant Property of Extract and Fractions Obtained from a Red Alga, Polysiphonia urceolata. Food Chemistry, 95, 27-43.

[47] Imlay, J.A. (2003) Pathways of Oxidative Damage. Annual Review of Microbiology, 57, 395-408. http://dx.doi.org/10.1146/annurev.micro.57.030502.090938

[48] Diplock, A.T. (1997) Will the “Good Fairies” Please Prove to Us That Vitamin E Lessens Human Degenerative of Disease? Free Radical Research, 27, 511-532. http://dx.doi.org/10.3109/10715769709065791

[49] Yildirim, A., Mavi, A. and Kara, A.A. (2001) Determination of Antioxidant and Antimicrobial Activities Rumex crispus L. Extracts. Journal of Agricultural and Food Chemistry, 49, 4083-4089. http://dx.doi.org/10.1021/jf0103572

[50] Aboul-Enein, A., El-Baz, F., El-Baroty, G., Youssef, A. and Abd El-Baky, H. (2003) Antioxidant Activity of Algal Extracts on Lipid Peroxidation. Journal of Medical Sciences, 3, 87-98. http://dx.doi.org/10.3923/jms.2003.87.98

[51] Dupon, F.M. (1992) Salt-Induced Changes in Ion Transport: Regulation of Primary Pumps and Secondary Transporters. In: Cooke, D.T. and Clarkson, D.T., Eds., Transport and Receptor Proteins of Plant Membranes, Plenum Press, New York, 91-100. http://dx.doi.org/10.1007/978-1-4615-3442-6_8

[52] Allen, G.J., Wyn Jones, R.G. and Leigh, R.A. (1995) Sodium Transport Measured in Plasma Membrane Vesicles Isolated from Wheat Genotypes with Differing $\mathrm{K}^{+} / \mathrm{Na}^{+}$Discrimination Traits. Plant, Cell \& Environment, 18, 105-115. 
http://dx.doi.org/10.1111/j.1365-3040.1995.tb00344.x

[53] Shi, H., Ishitani, M., Kim, C. and Zhu, J.K. (2000) The Arabidopsis thaliana Salt Tolerance Gene SOS1 Encodes a Putative $\mathrm{Na}^{+} / \mathrm{H}^{+}$Antiporter. Proceedings of the National Academy of Sciences of the United States of America, 97, 6896-6901. http://dx.doi.org/10.1073/pnas.120170197

[54] Garbarino, J. and Dupon, F.M. (1988) NaCl Induced a $\mathrm{Na}^{+} / \mathrm{H}^{+}$Antiport in Tonoplast Vesicles from Barley Roots. Plant Physiology, 86, 231-236. http://dx.doi.org/10.1104/pp.86.1.231

[55] Blumwald, E. and Poole, R.J. (1988) Salt Tolerance in Suspension Cultures of Sugar Beet. Induction of $\mathrm{Na}^{+} / \mathrm{H}^{+}$Antiport Activity at the Tonoplast by Growth in Salt. Plant Physiology, 83, 884-887. http://dx.doi.org/10.1104/pp.83.4.884

[56] Matoh, T., Ishikawa, T. and Takahashi, E. (1989) Collapse of ATP-Induced H Gradient by Sodium Ions in Microsomal Membrane Vesicles Prepared from Atriplex gmelini Leaves: Possibility of $\mathrm{Na}^{+} / \mathrm{H}^{+}$Antiport. Plant Physiology, 89, 180183. http://dx.doi.org/10.1104/pp.89.1.180

[57] Gaxiola, R.A., Rao, R., Sherman, A., Grisafi, P., Alper, S.L. and Fink, G.R. (1999) The Arabidopsis thaliana Proton Transporters, AtNhx1and Avp1, Can Function in Cation Detoxification in Yeast. Proceedings of the National Academy of Sciences of the United States of America, 96, 1480-1485. http://dx.doi.org/10.1073/pnas.96.4.1480

[58] Macfarlane, G.R. and Burchett, M.D. (2001) Photosynthetic Pigments and Peroxidase Activity as Indicators of Heavy Metal Stress in the Grey Mangrove, Avicennia marina (Forsk.) Vierh. Marine Pollution Bulletin, 42, 233-240. http://dx.doi.org/10.1016/S0025-326X(00)00147-8

[59] Parida, A.K., Das, A.B. and Mohanty, P. (2004) Defense Potentials to NaCl in a Mangrove, Bruguiera parviflora: Differential Changes of Isoforms of Some Antioxidative Enzymes. Journal of Plant Physiology, 161, 531-542. http://dx.doi.org/10.1078/0176-1617-01084

[60] Parida, A.K., Das, A.B. and Mohanty, P. (2004) Investigations on the Antioxidative Defense Responses to NaCl Stress in a Mangrove, Bruguiera parviflora: Differential Regulations of Isoforms of Some Antioxidative Enzymes. Plant Growth Regulator, 42, 213-226. http://dx.doi.org/10.1023/B:GROW.0000026508.63288.39

[61] Dasgupta, N., Nandy, P., Tiwari, C. and Das, S. (2010) Salinity-Imposed Changes of Some Isozymes and Total Leaf Protein Expression in Five Mangroves from Two Different Habitats. Journal of Plant Interactions, 5, 211-221. http://dx.doi.org/10.1080/17429140903438076

[62] Sharma, P., Jha, A.B., Dubey, R.S. and Pessarakli, M. (2012) Reactive Oxygen Species, Oxidative Damage, and Antioxidative Defense Mechanism in Plants under Stressful Conditions. Journal of Botany, 2012, 1-26. http://dx.doi.org/10.1155/2012/217037

[63] Hasegawa, P.M., Bressan, R.A., Zhu, J.K. and Bohnert, H.J. (2000) Plant Cellular and Molecular Responses to High Salinity. Annual Review of Plant Physiology and Plant Molecular Biology, 51, 463-499. http://dx.doi.org/10.1146/annurev.arplant.51.1.463

[64] Asada, K. (2006) Production and Scavenging of Reactive Oxygen Species in Chloroplasts and Their Functions. Plant Physiology, 141, 391-396. http://dx.doi.org/10.1104/pp.106.082040

[65] Kavitha, K., Venkataraman, G. and Parida, A. (2008) An Oxidative and Salinity Stress Induced Peroxisomal Ascorbate Peroxidase from Avicennia marina: Molecular and Functional Characterization. Plant Physiology and Biochemistry, 46, 794-804. http://dx.doi.org/10.1016/j.plaphy.2008.05.008

[66] Ye, Y., Tam Nora, F.Y., Wong, Y.S. and Lu, C.Y. (2003) Growth and Physiological Responses of Two Mangrove Species (Bruguiera gymnorrhiza and Kandelia candel) to Water Logging. Environmental and Experimental Botany, 49, 209-221. http://dx.doi.org/10.1016/S0098-8472(02)00071-0

[67] Abogadallah, G.M. (2010) Insights into the Significance of Antioxidative Defense under Salt Stress. Plant Signaling \& Behavior, 5, 369-374. http://dx.doi.org/10.4161/psb.5.4.10873

[68] Mohamed, A.A., Mohamed, A.M. and Mahmoud, M.S. (2010) Effect of Salt Stress on Some Defense Mechanisms of Transgenic and Wild Potato Clones (Solanum tuberosum L.) Grown in Vitro. Natural Science, 8, 181-193.

[69] Jayaramana, J. (1999) Laboratory Manual in Biochemistry. New Age International Publishers, New Delhi, 61-67.

[70] Huda-Faujan, N., Noriham, A., Norrakiah, A.S. and Babji, A.S. (2009) Antioxidant Activity of Plants Methanolic Extracts Containing Phenolic Compounds. African Journal of Biotechnology, 8, 484-489.

[71] Singleton, V.L. and Rossi, A. (1965) Colorimetry of Total Phenolics with Phosphomolybdic Phosphotungstic Acid Reagents. American Journal of Enology and Viticulture, 16, 144-158.

[72] Jia, Z.S., Tang, M.C. and Wu, J.M. (1999) The Determination of Flavonoid Contents in Mulberry and Their Scavenging Effects on Superoxide Radicals. Food Chemistry, 64, 555-559. http://dx.doi.org/10.1016/S0308-8146(98)00102-2

[73] Blois, M.S. (1958) Antioxidant Determinations by the Use of a Stable Free Radical. Nature, 26, 1199-1200. http://dx.doi.org/10.1038/1811199a0 
[74] Re, R.N., Pellegrini, A., Proteggente, A., Pannala, M., Yang, C. and Evans, R. (1999) Antioxidant Activity Applying an Improved ABTS Radical Cation Decolorization Assay. Free Radical Biology and Medicine, 26, 1231-1237. http://dx.doi.org/10.1016/S0891-5849(98)00315-3

[75] Haro-Vicente, J.F., Martínez-Graciá, C. and Ros, G. (2006) Optimization of in Vitro Measurement of Available Iron from Different Fortificants in Citric Fruit Juices. Food Chemistry, 98, 639-648. http://dx.doi.org/10.1016/j.foodchem.2005.06.040

[76] Das, S. and Mukherjee, K.K. (1997) Morphological and Biochemical Investigations on Ipomea Seedlings and Their Species Interrelationships. Annals of Botany, 79, 565-571. http://dx.doi.org/10.1006/anbo.1996.0384

[77] Shannon, L.M., Key, E. and Lew, J.Y. (1966) Peroxidase Isozyme from Horseraddish Root. I. Isolation and Physical Properties. The Journal of Biological Chemistry, 249, 2166-2172.

[78] Keith, H., Emmanuelle, V., Hélène, B. and Charistian, A. (1983) Superoxide Dismutase Assay Using Alkaline Dimethyl Sulfoxide as Superoxide Anion-Generating System. Analytical Biochemistry, 135, 280-287. http://dx.doi.org/10.1016/0003-2697(83)90684-X

[79] Hamilton, E.W. and Heckathorn, S.A. (2001) Mitochondrial Adaptations to NaCl Complex I Is Protected by AntiOxidants and Small Heat Shock Proteins, Whereas Complex II Is Protected by Proline and Betaine. Plant Physiology, 126, 1266-1274. http://dx.doi.org/10.1104/pp.126.3.1266

[80] Munns, R. (2002) Comparative Physiology of Salt and Water Stress. Plant, Cell \& Environment, 25, 239-250. http://dx.doi.org/10.1046/j.0016-8025.2001.00808.x

[81] Lea, P.J., Robinson, S.A. and Stewart, G.R. (1990) The Enzymology and Metabolism of Glutamine, Glutamate and Asparagine. In: Miflin, B.J., Ed., The Biochemistry of Plants, Academic Press, New York, 121-169.

[82] Robinson, S.A., Stewart, G.R. and Philips, R. (1992) Regulation of Glutamate Dehydrogenase Activity in Relation to Carbon Limitation and Protein Catabolism in Carrot Cell Suspension Culture. Plant Physiology, 98, 1190-1195. http://dx.doi.org/10.1104/pp.98.3.1190

[83] DiMartino, C. and Fuggi, A. (2001) Pattern of Free Amino Acids in Leaves of Salt Stressed Plants of Spinach. In: Proceedings of the 6th International Symposium on Inorganic Nitrogen Assimilation Congress, European Nitrate Ammonium Assimilation Group, Reims, 3-13.

[84] Gaspar, R.Z., Males, Z. and Vestermajer, G. (2004) TLC Analysis of Free Amino Acids in Althaeae Radix, Treated with Different $\gamma$-Irradiation Doses. Farmaceutski Glasnik, 60, 1-6.

[85] Arshi, A., Abdin, M.Z. and Iqbal, M. (2005) Ameliorative Effects of $\mathrm{CaCl}_{2}$ on Growth, Ionic Relations, and Proline Content of Senna under Salinity Stress. Journal of Plant Nutrition, 28, 101-125. http://dx.doi.org/10.1081/PLN-200042185

[86] Bartels, D. and Sunkar, R. (2005) Drought and Salt Tolerance in Plants. Critical Reviews in Plant Sciences, 24, 23-58. http://dx.doi.org/10.1080/07352680590910410

[87] Ebrahimzadeh, M.A., Pourmorad, F. and Bekhradnia, A.R. (2008) Iron Chelating Activity, Phenol and Flavonoid Content of Some Medicinal Plants from Iran. African Journal of Biotechnology, 7, 3188-3192.

[88] Mishra, S. and Das, A.B. (2004) Effect of Short-Term Exposure to NaCl on Photochemical Activity and Antioxidant Enzymes in Bruguiera parviflora, a Non-Secretor Mangrove. Acta Physiologiae Plantarum, 26, 317-326. http://dx.doi.org/10.1007/s11738-004-0022-y

[89] Jithesh, M.N., Prashanth, S.R., Sivaprakash, K.R. and Parida, A.K. (2006) Antioxidative Response Mechanisms in Halophytes: Their Role in Stress Defence. Journal of Genetics, 85, 237-254. http://dx.doi.org/10.1007/BF02935340

[90] Mallik, S., Nayak, M., Sahu, B.B., Panigrahi, A.K. and Shaw, B.P. (2011) Response of Antioxidant Enzymes to High $\mathrm{NaCl}$ Concentration in Different Salt-Tolerant Plant. Biologia Plantarum, 55, 191-195. http://dx.doi.org/10.1007/s10535-011-0029-3

[91] Turkan, I., Demiral, T. and Sekmen, A.H. (2013) The Regulation of Antioxidant Enzymes in Two Plantago Species Differing in Salinity Tolerance under Combination of Waterlogging and Salinity. Functional Plant Biology, 40, 484493. http://dx.doi.org/10.1071/FP12147

[92] Del Río, L.A., Sandalio, L.M., Corpas, F.J., Palma, J.M. and Barroso, J.B. (2013) Reactive Oxygen Species and Reactive Nitrogen Species in Peroxisomes Production, Scavenging, and Role in Cell Signaling. Plant Physiology, 141, 330335. http://dx.doi.org/10.1104/pp.106.078204

[93] Blokhina, O. and Fagerstedt, K.V. (2010) Reactive Oxygen Species and Nitric Oxide in Plant Mitochondria: Origin and Redundant Regulatory Systems. Physiologia Plantarum, 138, 447-462. http://dx.doi.org/10.1111/j.1399-3054.2009.01340.x

[94] Heyno, E., Mary, V., Schopfer, P. and Krieger-Liszkay, A. (2011) Oxygen Activation at the Plasma Membrane: Relation between Superoxide and Hydroxyl Radical Production by Isolated Membranes. Planta, 234, 35-45. http://dx.doi.org/10.1007/s00425-011-1379-y 
[95] Shah, K., Kumar, R.G., Verma, S. and Dubey, R.S. (2001) Effect of Cadmium on Lipid Peroxidation, Superoxide Anion Generation and Activities of Antioxidant Enzymes in Growing Rice Seedlings. Plant Science, 161, 1135-1144. http://dx.doi.org/10.1016/S0168-9452(01)00517-9

[96] Sharma, P. and Dubey, R.S. (2007) Involvement of Oxidative Stress and Role of Antioxidative Defense System in Growing Rice Seedlings Exposed to Toxic Concentrations of Aluminum. Plant Cell Reports, 26, 2027-2038. http://dx.doi.org/10.1007/s00299-007-0416-6 